Case Report

\title{
Emergence in Elderly Patient Undergoing General Anesthesia with Xenon
}

\section{Maria Sanfilippo, Ahmed Abdelgawwad Wefki Abdelgawwad Shousha, and Antonella Paparazzo}

Department of Anesthesiology and Intensive Care, Sapienza University, Viale del policlinico 155, 00161 Rome, Italy

Correspondence should be addressed to Ahmed Abdelgawwad Wefki Abdelgawwad Shousha; dott.ahmed@gmail.com

Received 4 April 2013; Accepted 1 May 2013

Academic Editors: A. Apan, R. S. Gomez, A. Han, and C. Seefelder

Copyright (C) 2013 Maria Sanfilippo et al. This is an open access article distributed under the Creative Commons Attribution License, which permits unrestricted use, distribution, and reproduction in any medium, provided the original work is properly cited.

\begin{abstract}
Introduction. It is a consensus that the postoperative cognitive function is impaired in elderly patients after general anaesthesia, and such category patient takes more time to recover. Xenon is a noble gas with anesthetic properties mediated by antagonism of $\mathrm{N}$ methyl-D-aspartate receptors. With a minimum alveolar concentration of 0.63 , xenon is intended for maintaining hypnosis with $30 \%$ oxygen. The fast recovery after xenon anaesthesia was hypothesized to be advantageous in this scenario. Case Presentation. We report the case of 99 -year-old woman who underwent sigmoid colon carcinoma resection with colorectal anastomosis. We carried out the induction phase by propofol, oxygen, fentanil, and rocuronium bromide, and then we proceeded to a rapid sequence endotracheal intubation consequently. The patient was monitored by IBP, NIBP, ECG, cardiac frequency, respiratory rate, capnometry, TOF Guard, blood gas analysis, and BIS. For maintenance we administrated oxygen, remifentanil, rocuronium bromide, and xenon gas $60-65 \%$. Shortly after the end of surgery the patients started an autonomous respiratory activity, and a high BIS level was also recorded. Decision was made by our team to proceed into the emergence phase. The residual neuromuscular block was antagonized by sugammadex, modified Aldrete score was implicated, and we got our patient fully awake without any cognitive dysfunction or delirium. Conclusion. The rapid emergence to full orientation in very elderly patient who had been anesthetized by xenon shows concordance to the high BIS values and the clinical signs of the depth of anesthesia.
\end{abstract}

\section{Introduction}

Aging is an irreversible and progressive physiological phenomena characterized by degenerative changes in the structure and functional reserve of organs and tissues [1]. Advances and improvement in medical science have increased life expectancy, and thus perioperative surgery and anesthesia in the elderly patient have become an extremely important issue.

Elderly patients (arbitrarily defined as being over 65 years of age) are vulnerable to the adverse effects of anesthesia because of their reduced margin of safety. Morbidity and mortality increase with advancing age, with a steep increase after the age of 75 years [2]. The frequency of complications related to anesthesia is $0.5 \%$ in patients $>80$ years old [3].

Elderly patients often take more time to recover completely from the central nervous system effects of general anesthesia, particularly if they were confused or disoriented preoperatively.

Over the last decade there has been renewed interest in the use of xenon as an anaesthetic, and xenon has been licensed as an anesthetic in Europe since 2005. Xenon potently inhibits N-methyl-D-aspartate (NMDA) noncompetitively, with little effect on GABAA receptors or nonNMDA glutamatergic receptors.

The main beneficial features of xenon anesthesia are fast induction and emergence because of low solubility in blood and tissues, along with remarkably stable hemodynamics even in patients with impaired cardiac function.

Xenon has proven to be a safe and well-tolerated anesthetic in clinical trials $[4,5]$.

In comparison with nitrous oxide, Goto and colleagues found that emergence from xenon anesthesia is 2 or 3 times faster than that from comparable MACs of nitrous 
oxide/isoflurane and nitrous oxide/sevoflurane anesthesia. Furthermore, xenon compares favorably with other anesthetic agents [6].

\section{Case Presentation}

A 99-year-old female (height $1.60 \mathrm{~m}$; weight $45 \mathrm{~kg}$, ASA III) was admitted to our hospital and underwent major abdominal surgery (sigmoid colon carcinoma resection with colorectal anastomosis) under general anesthesia, and the surgery duration was about 220 minutes. Her medical history revealed mild degree heart failure, chronic normocytic anemia, gastritis, and allergy for NSAIDs and penicillin antibiotics.

Her preoperative laboratory tests: hemoglobin $8.8 \mathrm{mg}$ $\cdot \mathrm{dL}^{-1}$, hematocrit $30.9 \%$, leukocytes $11,500 \mathrm{~mm}^{-3}$ without deviation, platelets $453,000 \mathrm{~mm}^{-3}$, sodium $131 \mathrm{mg} \cdot \mathrm{dL}^{-1}$, potassium $4 \mathrm{mg} \cdot \mathrm{dL}^{-1}$, magnesium $0.58 \mathrm{mg} \cdot \mathrm{dL}^{-1}$, creatinine $0.5 \mathrm{mg} \cdot \mathrm{dL}^{-1}$, and total calcium $8.24 \mathrm{mg} \cdot \mathrm{dL}^{-1}$.

In the preoperative room we prepared our patient by antibiotics prophylaxis: ciprofloxacin $2 \mathrm{gm}$; metronidazole $500 \mathrm{mg}$ and an antiemetic agent; ondansetron $4 \mathrm{mg}$.

Our patient was monitored by pulse oximetry, expiratory capnography, invasive and noninvasive blood pressure, electrocardiogram, bispectral index (BIS), neuromuscular transmission (TOF Guard), and diuresis.

A peripheral venous access $(20 \mathrm{G})$ was established in upper right limb, and also a central venous access was done immediately after the induction phase as it was needed for postoperative chemotherapy afterwards.

We induced our anesthesia by oxygen, propofol $50 \mathrm{mg}$, fentanil $100 \mathrm{mcg}$, and rocuronium bromide $30 \mathrm{mg}$, and then we proceeded to a rapid sequence endotracheal intubation (tube diameter was $6.5 \mathrm{~mm}$ ),

The maintenance of the anesthesia was achieved by continuous infusion of remifentanil in a dose of $0.2 \mathrm{mcg} / \mathrm{kg} / \mathrm{min}$, rocuronium bromide $10 \mathrm{mg}$, xenon $60-65 \%$, and $\mathrm{O}_{2} 35-$ $40 \%$, the fluid replacement was calculated depending on her diuresis, plasma fluid, intraoperative blood loss, and anemia, and she was refunded by ringer lactate $1500 \mathrm{~mL}$, Nacl $0.9 \%$ $1000 \mathrm{~mL}$, fresh plasma fluids $1000 \mathrm{~mL}$, and packed red cells $500 \mathrm{~mL}$

A closed-circuit anesthesia machine (Felix Dual, Taema) was used for xenon gas delivery. The ventilation parameters were the following: "pressure-cycled mechanical ventilation with inhalation pressure indexes of $19 \mathrm{~cm} \mathrm{H}_{2} \mathrm{O}$, respiratory frequency 12 incursions per minute, $\mathrm{PEEP} 5 \mathrm{~cm} \mathrm{H}_{2} \mathrm{O}, \mathrm{FiO}_{2}$ $35-40 \%$, and inspiratory/expiratory time ratio $1: 2$, and the exhaled tidal volume was around $380 \mathrm{~mL}$."

Blood gas analysis was performed twice: 30 minutes after the start and 30 minutes before the end of surgery.

We registered electrolyte disorders, and they were resolved by administration of KCL $40 \mathrm{mEq}$ and $\mathrm{Ca}^{++}$gluconate in dose of $1 \mathrm{~g} \cdot 10 \mathrm{~m}^{-1}$ (Tables 1 and 2).

After 5 minutes from the end of the surgery we noticed our patient starting a voluntary respiratory activity with a high BIS level, so we decided to proceed for the emergence
TABLE 1: Hemogasanalysis 30 minutes after the start of the surgery.

\begin{tabular}{|c|c|c|}
\hline Status: & \multicolumn{2}{|c|}{ Accepted } \\
\hline Analysis: & \multicolumn{2}{|c|}{ 25/01/2013 09:32:29 } \\
\hline Sample Type: & \multicolumn{2}{|c|}{ Arterial } \\
\hline $\mathrm{S} / \mathrm{N}:$ & \multicolumn{2}{|c|}{08071675} \\
\hline \multicolumn{3}{|l|}{ Measured $\left(37.0^{\circ} \mathrm{C}\right)$} \\
\hline $\mathrm{pH}$ & 7.51 & \\
\hline$p \mathrm{CO}_{2}$ & 31 & $\mathrm{mmHg}$ \\
\hline $\mathrm{pO}_{2}$ & 187 & $\mathrm{mmHg}$ \\
\hline $\mathrm{Na}^{+}$ & 134 & $\mathrm{mmol} / \mathrm{L}$ \\
\hline $\mathrm{K}^{+}$ & 3.1 & $\mathrm{mmol} / \mathrm{L}$ \\
\hline $\mathrm{Ca}^{++}$ & 1.08 & $\mathrm{mmol} / \mathrm{L}$ \\
\hline Glu & 125 & $\mathrm{mg} / \mathrm{dL}$ \\
\hline $\mathrm{Lac}$ & 0.9 & $\mathrm{mmol} / \mathrm{L}$ \\
\hline \multicolumn{3}{|l|}{ Oximeter } \\
\hline $\mathrm{tHb}$ & 9.0 & $\mathrm{~g} / \mathrm{dL}$ \\
\hline $\mathrm{O}_{2} \mathrm{Hb}$ & 96.2 & $\%$ \\
\hline $\mathrm{COHb}$ & 2.1 & $\%$ \\
\hline MetHb & 1.8 & $\%$ \\
\hline $\mathrm{HHb}$ & -0.1 & $\%$ \\
\hline $\mathrm{sO}_{2}$ & 100.1 & $\%$ \\
\hline \multicolumn{3}{|l|}{ Derivatives } \\
\hline $\mathrm{TCO}_{2}$ & 25.7 & $\mathrm{mmol} / \mathrm{L}$ \\
\hline BEecf & 1.7 & $\mathrm{mmol} / \mathrm{L}$ \\
\hline $\mathrm{BE}(\mathrm{B})$ & 1.9 & $\mathrm{mmol} / \mathrm{L}$ \\
\hline $\mathrm{Ca}^{++}(7.4)$ & 1.13 & $\mathrm{mmol} / \mathrm{L}$ \\
\hline $\mathrm{sO}_{2}(\mathrm{c})$ & 99.7 & $\%$ \\
\hline $\mathrm{HCO}_{3}{ }^{-}(\mathrm{c})$ & 24.7 & $\mathrm{mmol} / \mathrm{L}$ \\
\hline $\mathrm{HCO}_{3}^{-}$(std $)_{\text {standard }}$ & 26.4 & $\mathrm{mmol} / \mathrm{L}$ \\
\hline Hct (c) & 27 & $\%$ \\
\hline \multicolumn{3}{|l|}{ Inserted } \\
\hline Temp & 37.0 & ${ }^{\circ} \mathrm{C}$ \\
\hline \multicolumn{3}{|l|}{$\mathrm{O}_{2} /$ Vent } \\
\hline $\mathrm{FIO}_{2}$ & 35.0 & $\%$ \\
\hline
\end{tabular}

phase and extubation reversing the neuromuscular blocking by sugammadex in a dose of $100 \mathrm{mg}$ [7] with careful monitoring for her cardiovascular and respiratory functions. Both modified Aldrete score and BIS values were recorded (Table 3).

After 13 minutes we got the complete recovery of our patient, she was awake without any confusion state, delirium, or cognitive dysfunction, also she had excellent and stabile both hemodynamic and respiratory functions, postoperative pain control was achieved by continuous intravenous infusion of morphine ( $5 \mathrm{mg}$ over $24 \mathrm{~h}$ ), and she was transferred to ICU for close monitoring.

\section{Conclusion}

In our case we got surprised for the rapid emergence of our patient; this corresponds with the low blood gas partition coefficient of xenon (0.115). We also concluded that the BIS values show sufficient concordance with clinical signs of 
TABLE 2: Hemogasanalysis 30 minutes after the end of the surgery.

\begin{tabular}{|c|c|c|}
\hline Status: & \multicolumn{2}{|c|}{ Accepted } \\
\hline Analysis: & \multicolumn{2}{|c|}{ 25/01/2013 13:03:35 } \\
\hline Sample Type: & \multicolumn{2}{|c|}{ Arterial } \\
\hline $\mathrm{S} / \mathrm{N}:$ & \multicolumn{2}{|c|}{08071675} \\
\hline \multicolumn{3}{|l|}{ Measured $\left(37.0^{\circ} \mathrm{C}\right)$} \\
\hline $\mathrm{pH}$ & 7.33 & \\
\hline$p \mathrm{CO}_{2}$ & 45 & $\mathrm{mmHg}$ \\
\hline $\mathrm{pO}_{2}$ & 97 & $\mathrm{mmHg}$ \\
\hline $\mathrm{Na}^{+}$ & 131 & $\mathrm{mmol} / \mathrm{L}$ \\
\hline $\mathrm{K}^{+}$ & 5.0 & $\mathrm{mmol} / \mathrm{L}$ \\
\hline $\mathrm{Ca}^{++}$ & 1.25 & $\mathrm{mmol} / \mathrm{L}$ \\
\hline Glu & 178 & $\mathrm{mg} / \mathrm{dL}$ \\
\hline $\mathrm{Lac}$ & 2.3 & $\mathrm{mmol} / \mathrm{L}$ \\
\hline \multicolumn{3}{|l|}{ Oximeter } \\
\hline $\mathrm{tHb}$ & 9.7 & $\mathrm{~g} / \mathrm{dL}$ \\
\hline $\mathrm{O}_{2} \mathrm{Hb}$ & 95.0 & $\%$ \\
\hline $\mathrm{COHb}$ & 2.2 & $\%$ \\
\hline $\mathrm{MetHb}$ & 1.8 & $\%$ \\
\hline $\mathrm{HHb}$ & 1.0 & $\%$ \\
\hline $\mathrm{sO}_{2}$ & 99.0 & $\%$ \\
\hline \multicolumn{3}{|l|}{ Derivatives } \\
\hline $\mathrm{TCO}_{2}$ & 25.1 & $\mathrm{mmol} / \mathrm{L}$ \\
\hline BEecf & -2.2 & $\mathrm{mmol} / \mathrm{L}$ \\
\hline $\mathrm{BE}(\mathrm{B})$ & -2.3 & $\mathrm{mmol} / \mathrm{L}$ \\
\hline $\mathrm{Ca}^{++}(7.4)$ & 1.21 & $\mathrm{mmol} / \mathrm{L}$ \\
\hline $\mathrm{sO}_{2}(\mathrm{c})$ & 97.0 & $\%$ \\
\hline $\mathrm{HCO}_{3}^{-}(\mathrm{c})$ & 23.7 & $\mathrm{mmol} / \mathrm{L}$ \\
\hline $\mathrm{HCO}_{3}^{-}(\mathrm{std})_{\text {standard }}$ & 23.1 & $\mathrm{mmol} / \mathrm{L}$ \\
\hline $\operatorname{Hct}(\mathrm{c})$ & 29 & $\%$ \\
\hline \multicolumn{3}{|l|}{ Inserted } \\
\hline Temp & 37.0 & ${ }^{\circ} \mathrm{C}$ \\
\hline
\end{tabular}

TABLE 3: BIS: bispectral index.

\begin{tabular}{lcccc}
\hline Time & $1 \mathrm{~min}$ & $5 \mathrm{~min}$ & $10 \mathrm{~min}$ & $13 \mathrm{~min}$ \\
\hline BIS & 35 & 92 & 97 & 99 \\
Modified Aldrete & 5 & 7 & 9 & 10 \\
\hline
\end{tabular}

anesthetic depth and the emergence to full orientation in very elderly patient who had been anesthetized by xenon, and consequently we encourage more studies concerning the use of xenon in general surgery with such category of patients [8$11]$.

\section{Consent}

Written informed consent was obtained from the patient for publication of this paper and accompanying images.

\section{Conflict of Interests}

The authors declare that they have no competing interests.

\section{References}

[1] S. Muravchik, "Pharmacological changes of aging," in Proceedings of the 53rd ASA Annual Meeting Refresher Course, Lectures \#19, pp. 1-7, 2002.

[2] R. Raymond, "Anesthetic management of the elderly patient," in Proceedings of the 53rd ASA Annual Meeting Refresher Course, Lectures \#321, pp. 1-7, 2002.

[3] D. Warner and M. Warner, "Anesthetic risk and the elderly," in Syllabus on Geriatric Anesthesiology, pp. 1-4, ASA, 2002.

[4] Xenon-Based Anesthesia: Theory and Practice Jan-Hinrich Baumert, Department of Anaesthesiology, UMC, Open Access Surgery, Nijmegen, The Netherlands, 2009.

[5] T. Goto, H. Saito, M. Shinkai, Y. Nakata, F. Ichinose, and S. Morita, "Xenon provides faster emergence from anesthesia than does nitrous oxide- sevoflurane or nitrous oxide-isoflurane," Anesthesiology, vol. 86, no. 6, pp. 1273-1278, 1997.

[6] R. D. Sanders, N. P. Franks, and M. Maze, "Xenon: no stranger to anaesthesia," British Journal of Anaesthesia, vol. 91, no. 5, pp. 709-717, 2003.

[7] Bridion (Sugammadex) Summary of Product Characteristics available via the electronic Medicines Compendium, July 2009.

[8] M. Coburn, J. H. Baumert, D. Roertgen et al., "Emergence and early cognitive function in the elderly after xenon or desflurane anaesthesia: a double-blinded randomized controlled trial," British Journal of Anaesthesia, vol. 98, no. 6, pp. 756-762, 2007.

[9] D. Rörtgen, J. Kloos, M. Fries et al., "Comparison of early cognitive function and recovery after desflurane or sevoflurane anaesthesia in the elderly: a double-blinded randomized controlled trial," British Journal of Anaesthesia, vol. 104, no. 2, pp. 167-174, 2010.

[10] M. Derwall, M. Coburn, S. Rex, M. Hein, R. Rossaint, and M. Fries, "Xenon: recent developments and future perspectives," Minerva Anestesiologica, vol. 75, no. 1-2, pp. 37-45, 2009.

[11] L. S. Rasmussen, K. Larsen, P. Houx, L. T. Skovgaard, C. D. Hanning, and J. T. Moller, "The assessment of postoperative cognitive function," Acta Anaesthesiologica Scandinavica, vol. 45 , no. 3, pp. 275-289, 2001. 


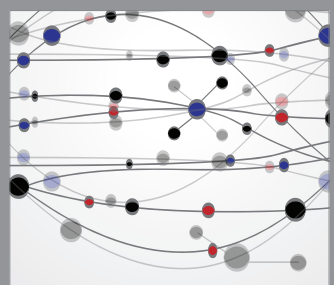

The Scientific World Journal
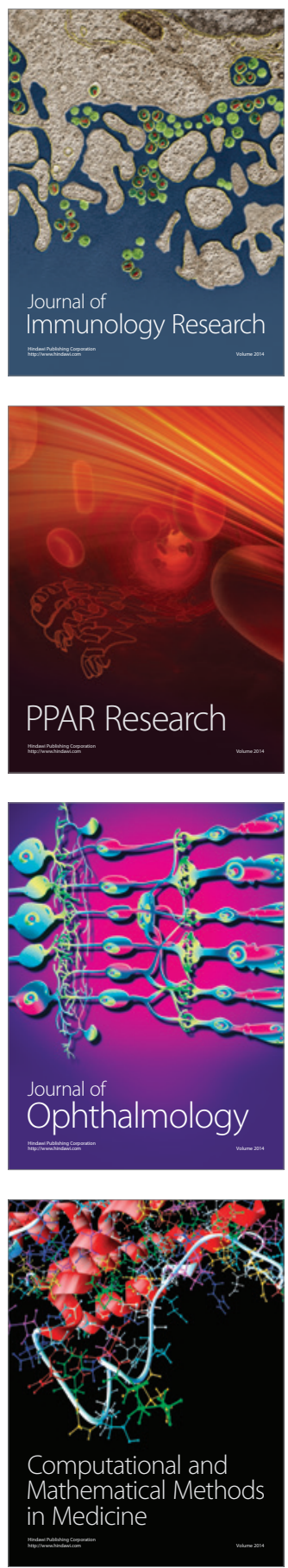

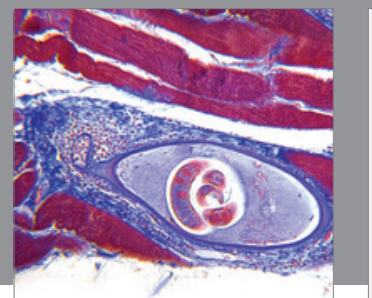

Gastroenterology

Research and Practice
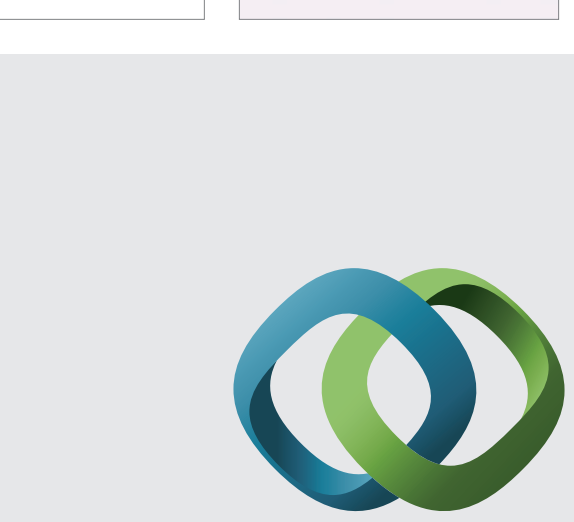

\section{Hindawi}

Submit your manuscripts at

http://www.hindawi.com
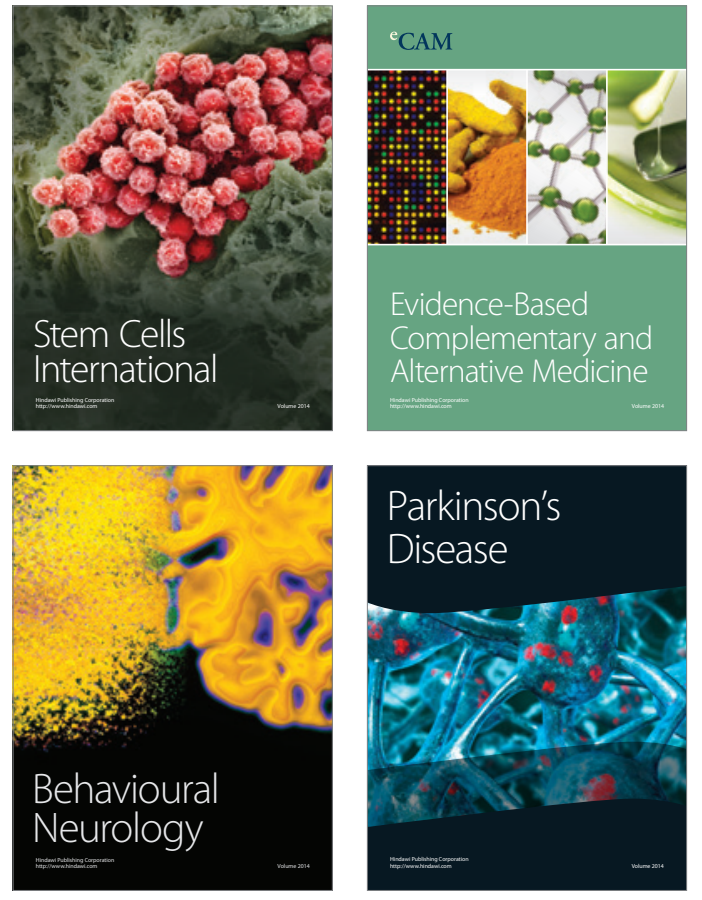
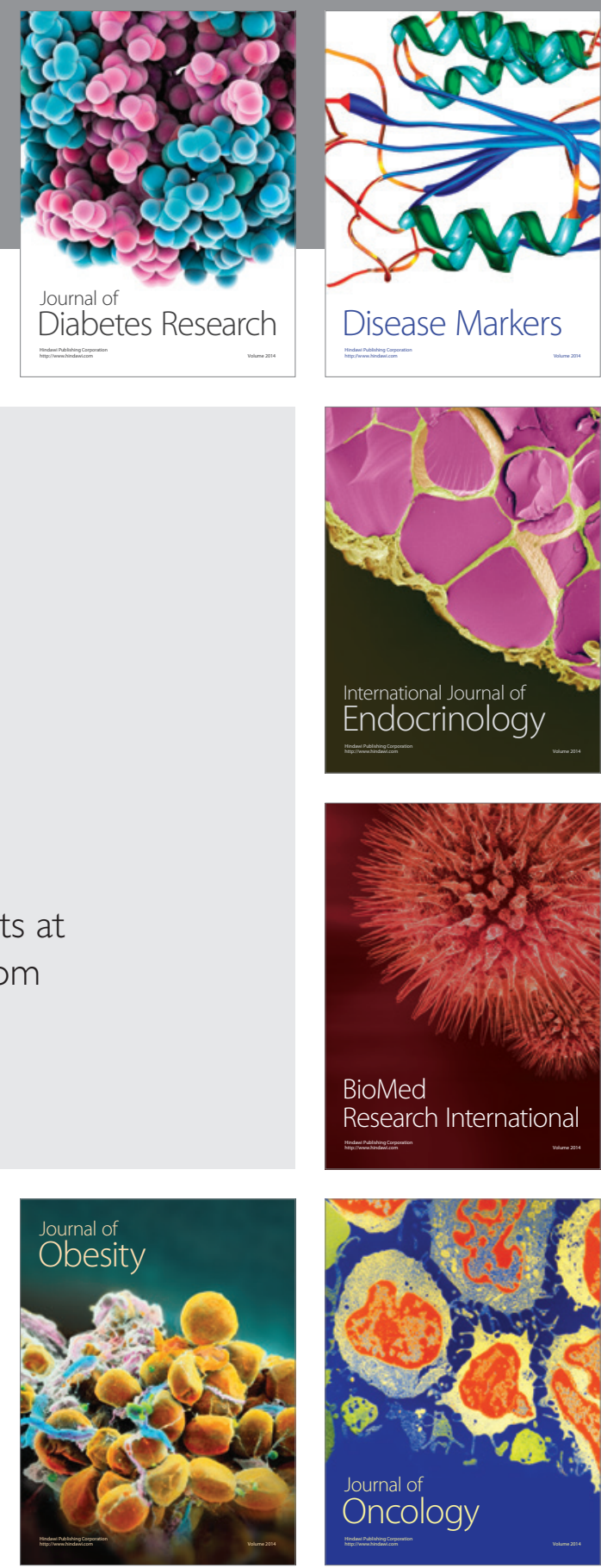

Disease Markers
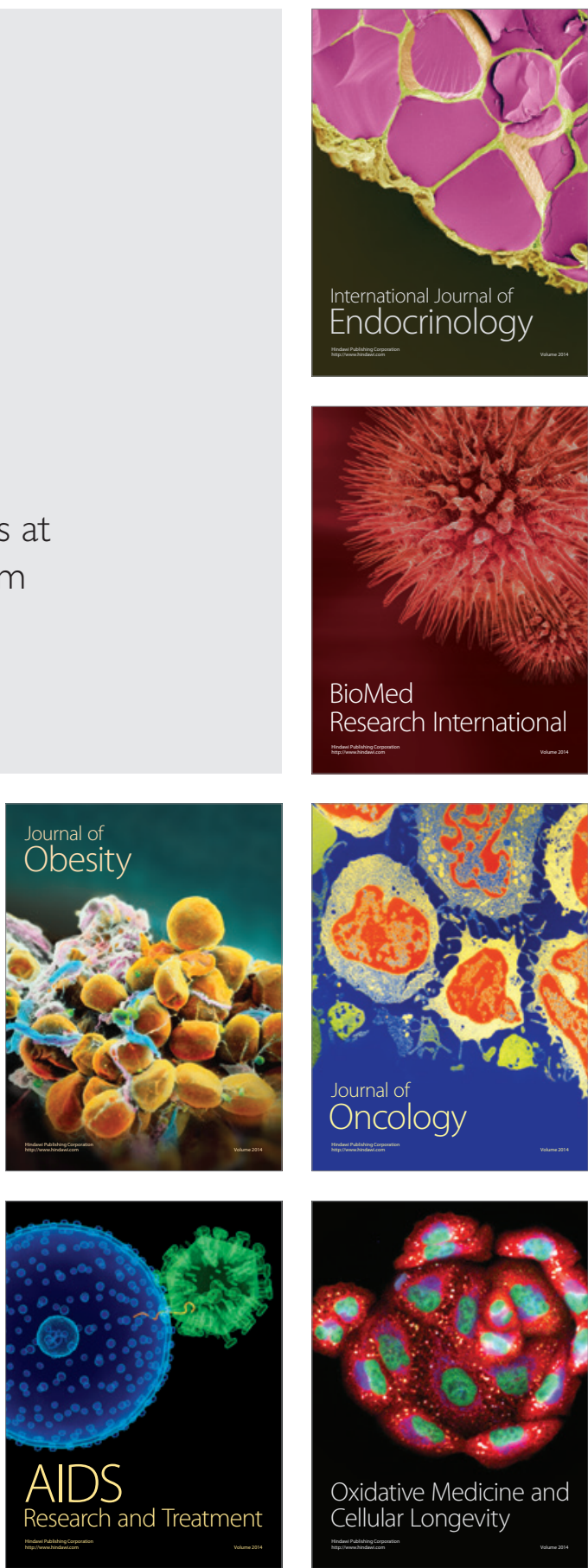